\title{
Egg Parasitization of Yellow Stem Borer and Leaf Folder of Rice under Prevailing Weather Parameters
}

\author{
Shriti Moses*, A.K. Misra, Deepak Ranjan Kishor and Pankaj Kumar \\ Department of Entomology, RPCAU, PUSA, Samastipur (Bihar), PIN-848125, India \\ *Corresponding author
}

\section{A B S T R A C T}

\begin{tabular}{|l|}
\hline Ke y w o r d s \\
$\begin{array}{l}\text { Stem borer, Leaf } \\
\text { folder, } \\
\text { Parasitization. }\end{array}$ \\
\hline Article Info \\
\hline $\begin{array}{l}\text { Accepted: } \\
\text { 17 November } 2018 \\
\text { Available Online: } \\
\text { 10 December } 2018\end{array}$ \\
\hline
\end{tabular}

\section{Introduction}

Rice is the staple food of more than 60 per cent world population and most of the people of South East Asia. About 90 per cent of rice grown in the world is produced and consumed in Asian region. The production and productivity of rice in Bihar is less than other states of the country due to diverse ecological and climatological condition apart from poor socio-economic condition of the farmers along with the poor management of the crop. In Bihar only 33 per cent of total rice land has got irrigation facilities and rest is totally depending upon rain. With the introduction of changes in types of varieties being cultivated, practicing of different cultivation systems and alterations in rice based cropping systems, certain pests earlier regarded as minor pests have now assumed significance as pests of regional significance. Weather factors are the main regulating causes for the insect pests populations under field conditions.

Investigation has revealed that rice ecosystem is very rich in natural enemies which are very useful in reducing the yield loss (Singh, 1990). Following inundative release of Trichogramma japonicum into a plot of rice in Assam, damage by stem borer moth was reduced by 54.9 per cent after 50 days (Borah, 1994). Study on biocontrol of yellow stem borer using Trichogramma revealed that 
reduction in yield average 1.64 per cent in treated plot as compared to with 10.3 per cent in untreated plot (Mohanraj et al., 1995). A study in Maharastra on rice variety, Ambemohor revealed that the parasitoid Trichogramma japonicum released @ 50,000 adults/ha was more effective in controlling Scirpophaga incertulas than endosulfan. Significant role played by parasitoid in suppression of stem borer can be shown by the study of Punjab, where it was observed that the mean percentage of egg parasitization by Telenomus dignus ranged from 35.28 to 43.21 , 3.66 to 12.06 and 17.82 to 30.22 during September, 1992 and August and September, 1993 respectively. While in case of Trichogramma japonicum it ranged from 1.55 to 6.23 during September, 1993 (Dulcha et al., 1994).

\section{Materials and Methods}

\section{Per cent parasitization of yellow stem borer egg}

To know the extent of egg parasitization of yellow stem borer, Scirpophaga incertulas egg masses were collected at weekly intervals from 5 randomly selected egg mass in the experimental plot from $2^{\text {nd }}$ week of August to October during kharif 2017. For the estimation of parasitism of yellow stem borer, $5 \mathrm{egg}$ masses were randomly collected from the unsprayed field at the weekly interval and brought to the laboratory to estimate the emergence of larvae and parasitoids. The egg masses were kept separately in glass vials which were provided with sufficient moisture to prevent desiccation of larvae and leaf pieces. The vials were covered with cotton and numbered with date. Egg masses were observed every day and were recorded on number of larvae hatched. Based on the number of emerged larvae and parasitoids the percent egg parasitisms were calculated.
Per cent parasitization $=$

Total number of parasitoids emerged X 100

Total number of eggs mass

The mean per cent parasitization of 5 randomly selected egg masses of yellow stem borer in rice cv. Rajendra Bhagwati during kharif 2017 were calculated.

\section{Per cent parasitization of leaf folder egg}

The egg parasitism by Trichogramma chilonis was estimated through sampling of leaf folder eggs. The parasitization was calculated from randomly selected eggs within 5 folded leaves. The collected eggs were brought to laboratory, healthy and parasitized eggs were kept under observation and the per cent of parasitization was worked out. The degree of parasitization on the different host eggs depends on the morphological characteristics of the egg and location on the leaf where egg masses were deposited. Eggs are laid singly in the leaf midrib within the folded leaf. Per cent damage by leaf folder at $45 \mathrm{DAT}$ and $60 \mathrm{DAT}$ were calculated then mean percent damage by leaf folder of 45 DAT and 60 DAT were worked out and data so obtained were subjected to analysis.

\section{Results and Discussion}

\section{Stem borer egg mass parasitization}

A regular survey of egg parasitization of yellow stem borer carried out from last week of July to fourth week of October during kharif 2017 in rice field of RPCAU, Pusa farm and data so obtained are presented in Table 1. Freshly laid five egg mass of stem borer were collected from the infested field at weekly interval. This egg mass were brought in the laboratory and kept in glass vials separately along with leaf pieces and vials were covered with cotton and observed every day for the 
emergence of larvae and parasites. Based on the number of emerged larvae and parasitoids percent egg mass parasitization was calculated.

Data revealed that maximum percent of egg parasitization by Trichogramma japonicum was observed in the $33^{\text {rd }}$ standard week of August (51.42\%). The meteorological parameters viz. maximum temperature, minimum temperature, morning relative humidity, evening relative humidity and rainfall during maximum parasitization were $31^{\circ} \mathrm{C}, 25.3^{\circ} \mathrm{C}, 94 \%, 79 \%$ and $214.4 \mathrm{~mm}$ respectively. The $36^{\text {th }}$ standard week of September showed (43.20\%) second position in percent egg parasitization.

Minimum percent of egg parasitization by Trichogramma japonicum was observed in the $30^{\text {th }}$ standard week of July $(3.03 \%)$. The meteorological parameters viz. maximum temperature, minimum temperature, morning relative humidity, evening relative humidity and rainfall during minimum parasitization were $32.1^{\circ} \mathrm{C}, 26.2^{\circ} \mathrm{C}, 86 \%, 75 \%$ and $31.4 \mathrm{~mm}$ respectively. The seasonal average of percent egg parasitization was ranged from $3.03 \%$ to $51.42 \%$ (Table 1). The yellow stem borer egg parasitization declined from last week of September.

In order to find out the relationship between egg parasitism of yellow stem borer and weather parameters, correlation coefficient were worked out and presented in Table 2. It is revealed that all the weather parameters showed positive correlation with maximum temperature, morning relative humidity and rainfall ( $\mathrm{r}=0.0363,0.4941$ and 0.5658$)$ and showed negative correlation with minimum temperature, evening relative humidity and wind velocity $(r=-0.3377,-0.2546$ and 0.2979) on egg parasitization of yellow stem borer during kharif2017. The multiple regression equation (Table 2) analysis revealed that the total variation in the egg parasitization of yellow stem borer were $70.3 \%$ contributed by aforesaid weather factors. From the correlation studies, it was obvious that all the aforesaid weather parameters had a definite role in the egg parasitization of yellow stem borer in rice field. Of these abiotic factors maximum temperature, morning relative humidity and rainfall are found to be congenial for egg parasitization of yellow stem borer. But lower egg parasitization of yellow stem borer may be due to temperature fluctuation and also due to less number of bio agent present in the field. The rainfall seems to have positive effect on egg parasitization of yellow stem borer. The findings are partly supported by Pandey et al., (2001) and Kumar et al., (2008). Pandey reported that yellow stem borer showed significant negative correlation with relative humidity. Kumar (2001) reported that the pest incidence was negatively correlated with morning and afternoon relative humidity. Baghel (2011) who recorded Telenomus sp. as active egg parasite of rice stem borer, which was found most active during the fourth week of October and capable in parasitizing 0$71.02 \%$ eggs at Raipur.

It may be stated that the Trichogramma japonicum is the most important egg parasitoid of rice stem borer egg at Pusa which was found most active during first week of August to last week of September.

\section{Leaf folder egg parasitization}

A regular survey of egg parasitization of egg parasitization of leaf folder carried out from last week of July to fourth week of October during kharif 2017 in rice field of RPCAU, Pusa farm and data so obtained are presented in Table 3. Data revealed that maximum egg parasitization of leaf folder was done by Trichogramma chilonis in the rice field during kharif 2017. 
Table.1 Influence of weather parameters on yellow stem borer egg parasitization during kharif 2017

\begin{tabular}{|c|c|c|c|c|c|c|c|c|}
\hline Month & $\begin{array}{c}\text { Std. } \\
\text { week }\end{array}$ & \multicolumn{2}{|c|}{$\begin{array}{c}\text { Temperature } \\
\left({ }^{0} \mathrm{C}\right)\end{array}$} & \multicolumn{2}{c|}{$\begin{array}{c}\text { Relative humidity } \\
(\%)\end{array}$} & $\begin{array}{c}\text { Rainfall } \\
(\mathrm{mm})\end{array}$ & $\begin{array}{c}\text { Wind speed } \\
(\mathrm{Km} / \mathrm{hr})\end{array}$ & Mean egg parasitization* \\
\cline { 2 - 7 } & & Max. & Min. & Morning & Evening & & & 03.03 \\
\hline Jul. & 30 & 32.1 & 26.2 & 86 & 75 & 31.4 & 8.7 & 27.30 \\
\hline Aug. & 31 & 33.0 & 26.3 & 90 & 77 & 12.4 & 3.6 & 43.18 \\
\hline Aug. & 32 & 32.8 & 26.5 & 93 & 79 & 116.3 & 5.2 & 51.42 \\
\hline Aug. & 33 & 31.0 & 25.3 & 94 & 79 & 214.4 & 4.1 & 42.40 \\
\hline Aug. & 34 & 33.2 & 26.8 & 87 & 71 & 41.8 & 4.7 & 36.15 \\
\hline Sept. & 35 & 32.8 & 26.5 & 88 & 76 & 02.6 & 5.5 & 43.20 \\
\hline Sept. & 36 & 33.9 & 26.3 & 88 & 65 & 11.2 & 3.3 & 28.79 \\
\hline Sept. & 37 & 34.0 & 27.0 & 91 & 71 & 02.6 & 3.4 & 37.40 \\
\hline Sept. & 38 & 33.5 & 26.1 & 88 & 70 & 30.0 & 6.0 & 26.92 \\
\hline Sept. & 39 & 34.3 & 25.8 & 88 & 62 & 00.0 & 3.1 & 29.78 \\
\hline Oct. & 40 & 33.2 & 25.0 & 87 & 70 & 00.0 & 3.6 & 28.09 \\
\hline Oct. & 41 & 33.1 & 25.0 & 89 & 69 & 03.5 & 4.2 & 24.81 \\
\hline Oct. & 42 & 33.4 & 22.8 & 88 & 63 & 00.0 & 3.5 & 18.72 \\
\hline Oct. & 43 & 31.5 & 20.8 & 90 & 66 & 00.0 & 2.8 & \\
\hline
\end{tabular}

*Mean parasitization of five egg masses

Table.2 Correlation between per cent parasitization of yellow stem borer egg masses and prevailing weather parameters

\begin{tabular}{|l|c|}
\hline Meteorological parameter & Correlation $(\mathrm{r})$ \\
\hline Temperature Maximum $\left(\mathrm{X}_{1}\right)$ & 0.0363 \\
\hline Temperature Minimum $\left(\mathrm{X}_{2}\right)$ & -0.3377 \\
\hline Morning relative humidity $\left(\mathrm{X}_{3}\right)$ & 0.4941 \\
\hline Evening relative humidity $\left(\mathrm{X}_{4}\right)$ & -0.2546 \\
\hline Rainfall $\left(\mathrm{X}_{5}\right)$ & 0.5658 \\
\hline Wind velocity $\left(\mathrm{X}_{6}\right)$ & -0.2979 \\
\hline
\end{tabular}

Multiple regression equation: $Y=-37.857+6.585\left(\mathrm{X}_{1}\right)+0.316\left(\mathrm{X}_{2}\right)-2.214\left(\mathrm{X}_{3}\right)+0.806\left(\mathrm{X}_{4}\right)+0.207\left(\mathrm{X}_{5}\right)-5.172\left(\mathrm{X}_{6}\right)$ Coefficient of determination $\left(\mathrm{R}^{2}\right): 0.703$ 
Table.3 Influence of weather parameters on leaf folder egg parasitization during kharif 2017

\begin{tabular}{|c|c|c|c|c|c|c|c|c|}
\hline \multirow[t]{2}{*}{$\begin{array}{l}\text { Mont } \\
\text { h }\end{array}$} & \multirow[t]{2}{*}{$\begin{array}{l}\text { Std. } \\
\text { week }\end{array}$} & \multicolumn{2}{|c|}{$\begin{array}{c}\text { Temperature } \\
\left({ }^{0} \mathrm{C}\right)\end{array}$} & \multicolumn{2}{|c|}{$\begin{array}{c}\text { Relative humidity } \\
(\%)\end{array}$} & \multirow[t]{2}{*}{$\begin{array}{l}\text { Rainfall } \\
\text { (mm) }\end{array}$} & \multirow[t]{2}{*}{$\begin{array}{l}\text { Wind speed } \\
(\mathrm{Km} / \mathrm{hr})\end{array}$} & \multirow[t]{2}{*}{$\begin{array}{c}\text { Mean egg } \\
\text { parasitization* }\end{array}$} \\
\hline & & Max. & Min. & Morning & Evening & & & \\
\hline Jul. & 30 & 32.1 & 26.2 & 86 & 75 & 31.4 & 8.7 & 00.00 \\
\hline Aug. & 31 & 33.0 & 26.3 & 90 & 77 & 12.4 & 3.6 & 04.72 \\
\hline Aug. & 32 & 32.8 & 26.5 & 93 & 79 & 116.3 & 5.2 & 29.19 \\
\hline Aug. & 33 & 31.0 & 25.3 & 94 & 79 & 214.4 & 4.1 & 42.40 \\
\hline Aug. & 34 & 33.2 & 26.8 & 87 & 71 & 41.8 & 4.7 & 36.42 \\
\hline Sept. & 35 & 32.8 & 26.5 & 88 & 76 & 02.6 & 5.5 & 30.26 \\
\hline Sept. & 36 & 33.9 & 26.3 & 88 & 65 & 11.2 & 3.3 & 33.60 \\
\hline Sept. & 37 & 34.0 & 27.0 & 91 & 71 & 02.6 & 3.4 & 31.15 \\
\hline Sept. & 38 & 33.5 & 26.1 & 88 & 70 & 30.0 & 6.0 & 34.16 \\
\hline Sept. & 39 & 34.3 & 25.8 & 88 & 62 & 00.0 & 3.1 & 19.80 \\
\hline Oct. & 40 & 33.2 & 25.0 & 87 & 70 & 00.0 & 3.6 & 15.18 \\
\hline Oct. & 41 & 33.1 & 25.0 & 89 & 69 & 03.5 & 4.2 & 18.36 \\
\hline Oct. & 42 & 33.4 & 22.8 & 88 & 63 & 00.0 & 3.5 & 21.20 \\
\hline Oct. & 43 & 31.5 & 20.8 & 90 & 66 & 00.0 & 2.8 & 12.25 \\
\hline
\end{tabular}

*Mean parasitization of five eggs

Table.4 Correlation between per cent parasitization of leaf folder egg masses and prevailing weather parameters

\begin{tabular}{|l|c|}
\hline Meteorological parameter & Correlation $(\mathbf{r})$ \\
\hline Temperature Maximum $\left(\mathbf{X}_{\mathbf{1}}\right)$ & 0.0964 \\
\hline Temperature Minimum $\left(\mathbf{X}_{\mathbf{2}}\right)$ & 0.3050 \\
\hline Morning relative humidity $\left(\mathbf{X}_{\mathbf{3}}\right)$ & 0.3812 \\
\hline Evening relative humidity $\left(\mathbf{X}_{\mathbf{4}}\right)$ & -0.0861 \\
\hline Rainfall $\left(\mathbf{X}_{\mathbf{5}}\right)$ & 0.4821 \\
\hline Wind velocity $\left(\mathbf{X}_{\mathbf{6}}\right)$ & -0.1776 \\
\hline
\end{tabular}


The percent parasitization by Trichogramma chilonis showed no definite trend and varied between 4.72 to 42.40 per cent with maximum parasitization in the $33^{\text {rd }}$ standard week of August. The egg parasitization was first noticed in the $31^{\text {st }}$ standard week of August and nil during $30^{\text {th }}$ standard week of July. The egg parasitization was not significant but maximum parasitization 42.40 per cent was recorded in the $33^{\text {rd }}$ standard week of August. The meteorological parameters viz. maximum temperature, minimum temperature, morning relative humidity, evening relative humidity and rainfall during maximum egg parasitization were $31^{\circ} \mathrm{C}, 25.3^{\circ} \mathrm{C}, 94 \%, 79 \%$ and $214.4 \mathrm{~mm}$ respectively. The minimum egg parasitization was 4.72 per cent in the $31^{\text {st }}$ standard week of August. The meteorological parameters viz. maximum temperature, minimum temperature, morning relative humidity, evening relative humidity and rainfall during maximum egg parasitization were $33^{\circ} \mathrm{C}$, $26.3^{\circ} \mathrm{C}, 90 \%, 77 \%$ and $12.4 \mathrm{~mm}$ respectively. The egg parasitization maintained no definite trend throughout the crop season during kharif 2017.

In order to find out the relationship between egg parasitism of leaf folder and weather parameters, correlation coefficient were worked out and presented in Table 4. It is revealed that all the weather parameters showed positive correlation with maximum temperature, minimum temperature, morning relative humidity and rainfall $(\mathrm{r}=0.0964$, $0.3050,0.3812$ and 0.4821 ) whereas, showed negative correlation with evening relative humidity and wind velocity $(\mathrm{r}=-0.0861$, 0.1776 ) on egg parasitization of yellow stem borer during kharif 2017. The multiple regression equation (Table 4) analysis revealed that the total variation in the egg parasitization of leaf folder were $52.5 \%$ contributed by aforesaid weather factors. From the correlation studies, it was obvious that all the aforesaid weather parameters had a definite role in the egg parasitization of leaf folder in rice field. Of these abiotic factors maximum temperature, minimum temperature, morning relative humidity and rainfall are found to be congenial for egg parasitization of leaf folder. But lower egg parasitization of yellow stem borer may be due to temperature fluctuation and also due to less number of bio agents present in the field. The evening relative humidity seems to have suppressive effect on egg parasitization of leaf folder. The findings are supported by Prabal Saikia and S. Parameswaram (2002) who reported that eggs parasitization of leaf folder eggs by $T$. chilonis revealed highest egg parasitization due to release of $T$. chilonis @ 1 lakh parasitoids/ha for six times.

It may be stated that the Trichogramma chilonis is the most important egg parasitoid of rice leaf folder egg at Pusa which was found most active during second week of August to fourth week of September.

\section{References}

Baghel, M. (2011). Studies on some important IPM tools influencive for the intensity of rice stem borer and its parasitoids. M.Sc. (Ag.) Thesis. Department of Entomology, IGKV, Raipur.pp.77.

Borah, R.K. (1994). Parasitization efficacy of Trichogramma japonicum on rice stem borer in Assam. Annals Agric. Res., 15(1): 124-125.

Dulcha, Brar S., Shenhmar M., Mahal M.S. and Singh R. (1994). Egg parasitoid of yellow stem borer, Scirpophaga incertulas (Walker) in Punjab. J. Insect Sci., 7(1): 61-63.

Kumar, A. and Sudhakar, T.R. (2001). Incidence of the yellow stem borer, Scirpophaga incertulas (Walker), on rice in relation to weather parameters. Solan, India Society of Pest 
Management and Economic Zoology. Pest Management and Economic Zoology. 9(2): 161-164.

Kumar, S., Khan, M.A., Kumar, A. and Sharma, K. (2008). Biodiversity of natural enemies in Paddy ecosystem and their seasonal dominance. Annals of Plant Protection Science. 16(2): 381383.

Mohanraj, P., Veenakumari, K. and Mandal, A.B. (1995). Biocontrol of yellow stem borer using Trichogramma $-\mathrm{a}$ parasitoid native to the Andamans. Rice Biotechnology Quaterly, 23: 9-10.

Pandey, V., Sharma, M.K. and Singh, R.S. (2001). Effect of weather parameters on light trap catches of yellow stem borer,
Scirpophaga incertulas Walker. New Delhi, India: Mrs. Aisha Shams. Shashpa. 8(1): 55-57.

Saikia, P., Parameshwaran, S. (2002). Ecofriendly strategies for the management of rice leaf folder, Cnaphalocrosis medinalis Guenee. New Delhi, India: Society of Plant Protection Sciences. Annals of Plant Protection Sciences. 10(1): 12-16.

Singh, S.P. (1990). Biological suppression of rice pests. An overview proceedings of Indo-USSR Joint workshop on problems and potentials of Biocontrol of pests and diseases. (June 26-28, 1990): 3156.

\section{How to cite this article:}

Shriti Moses, A.K. Misra, Deepak Ranjan Kishor and Pankaj Kumar. 2018. Egg Parasitization of Yellow Stem Borer and Leaf Folder of Rice under Prevailing Weather Parameters. Int.J.Curr.Microbiol.App.Sci. 7(12): 2385-2391. doi: https://doi.org/10.20546/ijcmas.2018.712.270 